\title{
Acetate metabolism in cancer cells
}

\author{
Aaron $\mathrm{M} \mathrm{Hosios}^{1}$ and Matthew G Vander Heiden ${ }^{1,2^{*}}$
}

Macromolecule biosynthesis is required to duplicate cell components and support proliferation. Studies examining the nutrients used by cancer cells have focused on the contribution of glucose and glutamine carbon for biosynthesis, but the importance of other metabolic fuels is becoming apparent. Labeling of two-carbon units in newly synthesized lipids has been used to infer the nutrients that contribute to the acetyl-CoA pools in cells. Glucose- and glutamine-derived carbon are known to contribute extensively to de novo lipid biosynthesis, and in this issue Kamphorst et al. find that extracellular acetate can also contribute substantially to this process [1]. In normoxia, glucose and glutamine together account for the majority of lipogenic acetyl-CoA, but this fraction falls substantially in hypoxia [2,3]. In hypoxia, flux from glucose to citrate as a source of acetyl-coA decreases, and cells utilize alternative carbon sources to generate this metabolite. Glutamine can provide some of this carbon through reductive carboxylation of glutaminederived $\alpha$-ketoglutarate to citrate [2,4], but a substantial amount of acetyl-CoA is labeled by neither glucose nor glutamine tracing. Breakdown of lipids scavenged from the environment is one alternate source of acetyl-CoA, but mammalian serum also contains acetate, and the authors found that exogenous acetate could be incorporated into acetyl-CoA and become available for lipid biosynthesis. Surprisingly, for some cell lines in hypoxia, acetate may be a major contributor to acetyl-CoA.

Acetate is transported into cells by members of the monocarboxylate transporter family [5] where acetyl-CoA synthetases (ACSS) catalyze conversion to acetyl-CoA. Mammalian cells express mitochondrial and cytosolic forms of ACSS, and the authors cite emerging data from other groups that this enzyme can be important for growth of some tumors. Kamphorst et al. observe that acetate labels acetyl-CoA in hypoxic cells only, and it is interesting to consider whether this is due to increased acetate uptake or increased ACSS activity in low oxygen.

\footnotetext{
* Correspondence: mvh@mit.edu

${ }^{1}$ Koch Institute for Integrative Cancer Research at Massachusetts Institute of Technology, Cambridge, MA 02139, USA

${ }^{2}$ Dana-Farber Cancer Institute, Boston, MA 02115, USA
}

Alternatively, it is possible that reduced synthesis of acetyl-CoA from glucose permits other sources of twocarbon units such as acetate to equilibrate with acetyl$\mathrm{CoA}$ and have a higher fractional contribution to pools in cells.

For the labeling experiments acetate was provided to cells exogenously, but Kamphorst et al.'s findings raise the question of what sources of acetate exist in vivo. Acetate is present in human and murine blood at concentrations ranging from $50-200 \mu \mathrm{M}$ [6-9] but has been estimated to be as high as $500-600 \mu \mathrm{M}$ by some $[10,11]$. There can be substantial variability of acetate concentrations across species with higher levels observed in cows relative to human, perhaps explaining why Kamphorst et al. measure high levels of acetate in bovine serum [12]. Acetate in plasma is supplied by both exogenous and endogenous sources. Exogenous acetate delivered to tumors via the blood may derive from the diet, with a substantial portion generated by gut microbiome metabolism of intestinal contents [13]. Fasting induces the liver to generate ketones for metabolism by other tissues. Starvation itself reduces circulating acetate [14], presumably because dietary sources of acetate are lacking; however when ketones are consumed by cells they generate acetyl-CoA. Finally, exogenous acetate can be generated from the oxidation of ethanol. In some individuals, this can be a major source of acetate, and chronic drinkers may have circulating acetate concentrations as high as the millimolar range $[10,15]$. In the hours following ethanol consumption, blood acetate has also been observed to reach similar levels [16], but it has also been suggested that ethanol-derived acetate is primarily trapped in the liver by high ACSS activity [13].

Acetate may also be generated in a cell's microenvironment. Protein deacetylases and acetyl-CoA hydrolase both generate acetate via hydrolysis reactions [14], suggesting that release of acetyl groups from endogenous sources may contribute to the acetate pool, and raising the possibility that some cells could produce acetate used by neighboring cells. Kamphorst et al. find that acetate's contribution to lipid biosynthesis is greatest when cells are hypoxic, suggesting that substantial acetate 
utilization occurs when exogenous sources delivered by the blood are not available. This argues that acetate produced locally in the microenvironment would be the major source available in this context. Future work should clarify the use of circulating acetate by tumors, or whether the contribution of locally generated acetate predominates. It will also determine the importance of acetate use for proliferation and tumor progression, and elucidate why the use of acetate might be advantageous to cancer cells.

Received: 17 November 2014 Accepted: 25 November 2014

Published online: 11 December 2014

\section{References}

1. Kamphorst JJ, Chung MK, Fan J, Rabinowitz JD: Quantitative analysis of acetyl-CoA production in hypoxic cancer cells reveals substantial contribution from acetate. Cancer \& Metabolism 2014, 2:23.

2. Metallo CM, Gameiro PA, Bell EL, Mattaini KR, Yang J, Hiller K, Jewell CM, Johnson ZR, Irvine DJ, Guarente L, Kelleher JK, Vander Heiden MG, Iliopoulos O, Stephanopoulos G: Reductive glutamine metabolism by IDH1 mediates lipogenesis under hypoxia. Nature 2012, 481:380-384.

3. Kamphorst JJ, Cross JR, Fan J, de Stanchina E, Mathew R, White EP, Thompson CB, Rabinowitz JD: Hypoxic and Ras-transformed cells support growth by scavenging unsaturated fatty acids from lysophospholipids. Proc Natl Acad Sci U S A 2013, 110:8882-8887.

4. Mullen AR, Wheaton WW, Jin ES, Chen PH, Sullivan LB, Cheng T, Yang $Y$, Linehan WM, Chandel NS, DeBerardinis RJ: Reductive carboxylation supports growth in tumour cells with defective mitochondria. Nature 2012, 481:385-388.

5. Moschen I, Broer A, Galic S, Lang F, Broer S: Significance of short chain fatty acid transport by members of the monocarboxylate transporter family (MCT). Neurochem Res 2012, 37:2562-2568.

6. Richards RH, Dowling JA, Vreman HJ, Feldman C, Weiner MW: Acetate levels in human plasma. Proc Clin Dial Transplant Forum 1976, 6:73-79.

7. Davies PG, Venkatesh B, Morgan TJ, Presneill JJ, Kruger PS, Thomas BJ, Roberts MS, Mundy J: Plasma acetate, gluconate and interleukin-6 profiles during and after cardiopulmonary bypass: a comparison of Plasma-Lyte 148 with a bicarbonate-balanced solution. Crit Care 2011, 15:R21.

8. Pomare EW, Branch WJ, Cummings $\mathrm{JH}$ : Carbohydrate fermentation in the human colon and its relation to acetate concentrations in venous blood. J Clin Invest 1985, 75:1448-1454.

9. Tollinger $\mathrm{CD}$, Vreman $\mathrm{HJ}$, Weiner MW: Measurement of acetate in human blood by gas chromatography: effects of sample preparation, feeding, and various diseases. Clin Chem 1979, 25:1787-1790.

10. Nuutinen $H$, Lindros K, Hekali P, Salaspuro M: Elevated blood acetate as indicator of fast ethanol elimination in chronic alcoholics. Alcohol 1985 2:623-626.

11. Remesy C, Demigne C, Chartier F: Origin and utilization of volatile fatty acids in the rat. Reprod Nutr Dev 1980, 20:1339-1349.

12. Sato H, Matsumoto M, Hanasaka S: Relations between plasma acetate, 3-hydroxybutyrate, FFA, glucose levels and energy nutrition in lactating dairy cows. J Vet Med Sci 1999, 61:447-451.

13. Buckley BM, Williamson DH: Origins of blood acetate in the rat. Biochem J 1977, 166:539-545.

14. Knowles SE, Jarrett IG, Filsell OH, Ballard FJ: Production and utilization of acetate in mammals. Biochem J 1974, 142:401-411.

15. Korri UM, Nuutinen $H$, Salaspuro M: Increased blood acetate: a new laboratory marker of alcoholism and heavy drinking. Alcohol Clin Exp Res 1985, 9:468-471.

16. Lundquist F: Production and utilization of free acetate in man. Nature 1962, 193:579-580

doi:10.1186/s40170-014-0027-y

Cite this article as: Hosios and Vander Heiden: Acetate metabolism in cancer cells. Cancer \& Metabolism 2014 2:27.

\section{Submit your next manuscript to BioMed Central and take full advantage of:}

- Convenient online submission

- Thorough peer review

- No space constraints or color figure charges

- Immediate publication on acceptance

- Inclusion in PubMed, CAS, Scopus and Google Scholar

- Research which is freely available for redistribution 